докладчика Комиссии ООН по правам человека Найджела Родли, посетившего Россию в 1994 году, условия содержания заключенных в России (особенно в СИЗО) являются "пыточными”. Определенный шаг в сторону выправления такого положения делается в настояшее время в форме передачи мест заключения в ведение Министерства юстиции.

В этот год, объявленный Организацией Объединенньх Наций годом прав человека, в год, когда мы отмечаем 50-летие Всеобщей декларации прав человека, необходима мобилизация законодательной, исполнительной и судебной власти, сознательной общественности, правозашитньх организаций для того, чтобы необходимые законодательные, организационные, просветительные меры создали перелом к лучшему в той области зашиты прав человека и гражданина, где их нарушения наиболее жестоки и бесчеловечны - в сфере деятельности органов правопорядка и уголовной юстиции. Успех подобных усилий послужит надежным показателем реальности нашего продвижения к свободному демократическому порядку, где эффективность борьбы с преступностњю идет рука об руку с эффективной зашитой наших гражданских конституционньх прав.

\title{
ДОПОЛНИТЕЛЬНЫЙ ПРОТОКОЛ О НЕМЕЖДУНАРОДНОМ ВООРУЖЕННОМ КОНФЛИКТЕ 1997 Г. И ПРОБЛЕМА БЕЖЕНЦЕВ
}

\section{И.П. Б л и щ е н к}

Немеждународный вооруженный конфликт является, как правило, результатом перерастания внутренней напряженности к широкомасштабному нарушению прав человека. И в этой связи немеждународный вооруженный конфликт является как бы высшей точкой нарушения прав и свобод человека. В России таким примером могут служить чеченские события, когда гражданская война поставила ряд вопросов нарушения прав и свобод человека. В данном случае юәчь шла не только

* Академик, профессор, доктор юридических наук, заслуженный деятель науки Российской Федерации, лауреат Международной премии имени Гуго Гроция. 
о нарушении ст. 3 Женевских конвенций о защите жертв войны, но и о неприменении всего Протокола П к этой ситуации, когда все стороны конфликта не приняли Протокол П о немеждународном вооруженном конфликте, хотя по Конституции РФ (п.4 ст. 15) они обязаны были сделать это.

Ратификация СССР в 1989 г. дополнительных протоколов 1977 г. сделала в соответствии с п. 4 ст. 5 Конституции СССР их обязательными для всех граждан и учреждений СССР и как из правопреемников СССР для учреждений и граждан Российской Федерации. Это наряду с тем, что и по Конституции РФ и по ряду законов все граждане России, в том числе и те, которые жили на территории Чечни должны были польоваться всеми правами и свободами. Однако война в Чечне не давала такой возможности, и на территории России появилась огромная масса беженцев, которые не пользовалась правами и свободами человека, провозглашенными во Всеобщей декларации прав человека, принятой в 1948 году.

СССР в последние годы установил официальный и неофициальный контакт с Верховным Комиссариатом по делам беженцев (UNCR) - штаб-квартира в Женеве) и участвовал на неправительственном уровне в различных симпозиумах и семинарах, где обсуждалась проблема беженцев, возможности расширения участия в работе Верховного Комиссариата, пересмотра конвенции и другие вопросы, касающиеся статуса беженцев и решения проблемы беженцев как таковой.

В 50-х годах СССР не участвовал ни в разработке конвенции и до последнего времени старался не иметь отношения с Верховным Комиссариатом. Основным аргументом в пользу такой позиции было следующее: неудовлетворительное определение беженца и, главным образом, квалификация беженцев из СССР сразу после Второй мировой войны и позднее как лищ, попадаюших под защиту конвенции и поэтому имеющих статус беженцев со всеми вытекающими правами на зашиту, проживание и убежнще в странах-членах конвенции. Если первый аргумент имел и имеет под собой определенное обоснование, т.к. это определение позволяет произвольно толковать понятие беженца, то второй аргумент носил ярко выраженный политический характер и не способствовал действительной защите беженцев.

С провозглашением независимости России положение изменилось.

В настоящее время число беженцев в мире составило около 20 млн. человек и причины, побудившие этих лиц стать беженцами, разные. Поэтому международное сообщество уже не удовлетворено определение беженца 1951 г., тем более, что это 
определение носит распльвчатый характер. Конвенция 1951 г. определяет беженца как лицо, которое "в силу вполне обоснованньх опасений стать жертвой преследований по признаку расы, вероисповедания, гражданства, принадлежности к определенной социальной группе или политических убеждений находится вне страны своей гражданской принадлежности".

В конвенции содержится важно положение: "запрещение принудительного возвращения", которое зашищало беженщев от принудительного возвращения в страну, где их жизнь, свобода будут подвергаться риску. Конвенция отразила ситуацию 1951 г. и определенно распространялась на Европу, на собьтия, имевшие место до 1951 г. в Европе. В 1967 г. был принят Протокол, которьй имел целью распространить действие конвенции на беженцев, которые появились в результате поздних событий в других частях мира.

К настоящему времени в Конвенции и в Протоколе участвуют более 100 государств.

Надо отметить, что определенная неудовлетворенность Конвенцией и Протоколом привела к появлению еще 30 других международньх соглашений о беженцах. Было разработано около 20 регионапьньх документов. Наиболее широкой сферой действия обладает Конвенщия Организащии Африканского единства (OAE) 1969 г. Эта Конвенция дает уже другое определение беженца, на мой взгляд, более реалистично отражајощее ситуацию: "термин "беженец" распространяется также на любое лицо, которое в результате внешней агрессии, оккупации, иностранного господства или событий, серьезно нарушающих обшественньй порядок ... вынуждено покидать свое обычное местожительство".

Можно сказать, что практически это определение в настоящее время применяется и в других частях мира. Обыгно Управление верховного комиссара по делам беженцев (УВКБ) не предоставляет помошь непосредственно беженцам, а по мере необходимости вьделяет средства правительственным организациям, добровольным учреждениям и освободительным движениям для осуществления проектов по оказанию чрезвычайной помощи, а также для осушествления программ содействия самообеспечению и интеграции. В настояшее время Верховным комиссаром по делам беженцев является профессор - специалист в области Мехдународньх отношений Содако Оната из Японии, избранная на этот пост в 1989 r.

УВКБ сотрудничает с другими учреждениями системы ООН: Детский фонд, Всемирная Организачия Здравоохранения, Мировая продовольственная программа, такими неправительственными организациями, как Международный Комитет Красного Креста, всего с 300-ми неправительственньми организациями. 
Ocобое место в сотрудничестве УВКБ занимает Ближневосточное агентство ООН для помощи палестинским беженцам и организации работ (БАПОР), созданное в 1949 г. Полномочия УВКБ не распространяются на палестинцев, это основная задача БАПОР, которое существует отдельно, со своим отдельньм бюджетом. Оно оказывает материальную помошь палестинским беженцам в конкретньх географических районах, в том числе в Иордании, Ливане, Сирии и на оккупированных территориях, а помощь направляется на осуществление деятельности в области образования, здравоохранения и коммунальньх услуг. БАПОР не располагает конкретньми полномочиями по защите беженцев, а правового документа, определяющего минимальные нормы обращения с ними в принимающпх странах не существует.

Положение беженцев в различньхх странах различно и зависит и от экономического положения в стране, и от ее законов. Многие государства практически не пускают беженцев в свои страны, а если и пускают, то они находятся в специальньгх "резервациях" (Таиланд в отношении камбодкийских беженцев, Гонконг в отношении китайских и вьетнамских беженцев). Даже в странах, предоставивших убежище, беженцы не всегда находятся в безопасности, возрастает число нападений на лагеря беженцев (Ливан, Мозамбик, Ботсвана, Лесото, Гондурас). В ряде стран беженцы подлежат призыву на военную службу государства пребывания (Сомали, Гондурас).Государства идут на вьцворение беженцев (так, в Восточной Африке правительства Уганды, Кении и Танзании “обменялись" беженцами, чтобы бросить своих политических противников снова в тюрьмы или казнить, в Пакистане - “стране революции” выкрали беженцев из Ирана с тем, чтобы их казнить). Все больше распространяется практика выцворения массы беженцев. В 1979 г., например, правительство Таиланда выдворило 40 тыс. камбоджийских беженцев как "незаконно въехавших", в Мексике это коснулось гватемальских беженцев, в Джибути - эфиопских беженцев, в Папуа-Новой Гвинее - индонезийских беженцев. В развитьд странах Европы, США и Канаде введены квоты приема беженцев, что позволяет использовать проблему беженцев и для оказания давления на страны, и для обеспечения “утечки мозгов", так как эти страны присвоили себе право в каждом случае решать вопрос, кто может, по их мнению, считаться беженцем и, следовательно, быть допущен в страну, т.е. отбирать "выгодньг”" для них беженцев. А в докладе, подготовленном сотрудниками Американского предпринимательского института предлагается, чтобы США расширили легальную эмиграцию с целью устранения предполагаемой нехватки рабочей силы и предоставляли 
ежегодно 150 тыс. разрешений на въезд для жителей Восточной Европы. В докладе рекомендуется "предварительно отбирать большое количество иммигрантов по конкретной специальности и другим профессиям, нехватка которых или даже отсутствие существует в США". Авторы доклада прямо пишут: “Учитывая, что тысячи талантливьх людей желают уехать из стран Восточной Европы, сейчас имеется подходящий момент для того, чтобы резко увеличить число иммигрантов из восточноевропейских стран".

Пользуясь неопределенностью общего определения "беженца”, в Конвенции 1951 г. практически вопрос о статусе лица, желающего въехать и выехать в ту или иную страну, решается произвольно. Так, например, в 1985 г. правительство Великобритании ввело ограничения на визы лицам из Шри-Ланки, европейские правительства ввели штрафы и меры наказания авиакомпаний, доставляюших из стран “третьего мира" лищ, которые безуспешно пытаются объявить себя беженцами. В США иммиграционные власти на многих прибывших оказывают давление с целью согласиться на "добровольный отъезд", высылая даже насильственно тысячи сальвадорцев, гаитянцев. В Европе многие беженцы сталкиваются с проблемой устройства на работу, есть основания считать, как пишет западная печать, что решения принимаются на основании политических и расовых соображений. В Германии, например, туркам и пакистанцам почти полностью отказано в статусе беженцев, а в США в 1982 г. только 26 из 12 тыс. сальвадорцев получили статус беженца. В 80-е годы из США и стран Западной Европы все больше и больше беженцев выдворялись насильственно: латиноамериканцы из США, тамильцы из Голландии, турки из Германии, заирцы из Швейцарии.

Проблєму беженцев следует отличать от проблемы иммитрации, политического убежища и свободы передвижения, хотя они тесно связаны. Очевидно, что во всех случаях возникает вопрос о разработке специальньх международньх соглашений и в целях упорядочения отношений между странами, и в целях обеспечения лучшей защиты как прав и свобод лиц, оказавшихся в сложных ситуациях, так и интересов государств и местных граждан, вовлеченных в эти отношения. Тем более, что в ряде стран (в том числе в России) возникла проблема так называемых “внутренних беженцев", положение которьх во многих случаях никак не определено международньм соглашением.

В этой связи, например в Чечне, когда в соответствии с Хасавюртскими соглашениями будет решаться вопрос о статусе Чечни путем голосования, в нем, на мой взгляд должны участ- 
вовать все лица, имевшие прописку в Чечне и ставшие беженцами. Очевидно, что наряду с международными соглашениями необходима разработка внутренних, используя в этих целях и опьт законов в таких странах, как Швеция, Финляндия, Норвегия, где, на мой взгляд, наиболее полно учтен опьт, хотя и они имеют свои недостатки (см. также Рез. Генеральной Ассамблеи OOH № 43/116, 42/110; E/1988/12; E/CN.4/1988/88).

В западной литературе широко обсуждается проблема обязательной репатриации беженцев в страны исхода, особенно после устранения причин, вызвавших поток беженцев. Верховный комиссар по делам беженцев читает, что главное внимание УВКБ сегодня долхно уделять разработке превентивньх мер в странах, где возникает опасность появления беженцев, с тем, чтобы предотвратить потоки беженцев и затем сосредоточить усилия международного сообщества на обеспечении беспрепятственного и безопасного возвращения беженцев в свои страны.

Представляется, что международное сообщество встало перед необходимостъю разработки новой международной конвенции о беженцах с учетом новой категории беженцев, возможностей принимающих стран, международной их защиты и помощи. При этом надо иметь в виду, что многие государства в настоящее время не хотят по разным причинам такой новой конвенции, однако сама жизнь их заставляет пересматривать свои позиции, и поэтому процесс осознания необходимости нового правового регулирования этой проблемы будет продолхаться. В этой связи Россия может выступить инициатором начала этого процесса в наших собственных интересах. Необходима в этой же связи разработка специальной международной конвенции о свободе выезда и въезда в другую страну (в настояшее время в Подкомиссии Комиссии ООН по правам человека создана рабочая групла, которая начала исследование проблемы свободы выезда, возврашения в свою страну и въезда в другую, но эта работа практически рассчитана на годы, а наше быстрое время уже сейчас ставит эти вопросы перед странами). Это соглашение могло бы предусмотреть в том числе и финансовые вопросы, консульскую защиту граждан, совместные действия государств по борьбе с возможными преступлениями и др. Это особенно важно в контексте строительства обшеевропейского дома, процесса OБCE. 